\title{
Investment in Secondary School Education: Which Way Forward to Reduce the Cost of Education in Siaya County?
}

\author{
James Ochieng Sika \\ Department of Education Management \\ Maseno University \\ Prof. F.Q.Gravenir \\ Department of Education Management \\ Kenyatta University,Nairobi, Kenya. \\ Dr. Andrew Riechi \\ Department of Education Planning \\ Nairobi University, Nairobi, Kenya.
}

\begin{abstract}
Unit cost of secondary education has continued to rise both direct and indirect jeopardizing access to basic education. The debate has concentrated on whom is carrying the burden of secondary education. However debate on strategies has never been in the focus. This study brings to the fore some specific strategies that can reduce the cost of education. The descriptive and causal comparative designs were used in this study. The study sample comprised 85 headteachers', 765 teachers', 3349 students and one DEO. The findings of the study indicate that on average 86 percent households are low income earners and therefore unable to pay fees and secondary schools are owed millions of shillings by fee defaulters. Among the strategies proposed include reducing charges on non-discretionary items and building day schools.
\end{abstract}

Key Words: Unit cost, Households, bursary, school fees, grants

\section{INTRODUCTION}

Different regions have used different models for investing in secondary schooling. For instance, in the early 1960s, there emerged the thinking that schooling could make office clerks, shopworkers, and farmers more productive in the USA (Goldin, 2001). This thinking constituted a shift in education policy from physical to human capital investment. The shift necessitated more investment in secondary school education which was then characterized by public funding and provision, non-selective with no early specialization or academic segregation, an academic and yet practical curriculum, numerous small- fiscally independent schools and school districts, and secular control of schools and school funds. Though deemed by many as being attractive due to its egalitarian and non-elitist qualities, this system has now been accused by its critics of lacking in standards and accountability. The decentralized nature of the US secondary school system increased investment though it led to funding inequalities (World Bank, 2005).

In OECD countries, investment in secondary education has focused mainly on cost effectiveness. The role of private sector in investment in secondary education has been enhanced and proactively encouraged by governments. This includes the use of distance learning, ICT, and courses adapted for second chance students and adults. Although in OECD 
countries, education is not compulsory beyond age 16, more than 80 percent of students continue learning either in formal senior secondary schools or in vocational training institutions, which most often combine applied learning with apprenticeship. Investment in secondary education has focused mainly in renewal of curricular along with various structural and managerial reforms (OECD, 2005).

In contrast to the investment in secondary education in developed and then developing countries, investment in secondary education in Sub-Saharan Africa continues to focus largely on expanding enrollment rather than on higher per student spending, and the pupil teacher ratio, which had been declining, is now up to 40 pupils per teacher (UNESCO, 2002). Falling revenues of secondary schools in many Africans countries led to the introduction of user fees as an ad hoc response to expenditure cuts-either imposed by falling government revenues. Throughout the 1980s and much of the 1990s the world bank especially pushed user fees on the grounds that low demand for poor quality services, rather than cost, was the principal barrier to expanding access. Poor parents often find it difficult to make a projection of the payoff of their children's education and cannot capture all the benefits of schooling, since these accrue across a child's lifetime and are difficult to access (Herz and Sperling, 2005).

According to World Bank (2005), eliminating user fees requires major front-end capital investment. These investments have highly significant implications for recurrent costs. In the medium term, expanding access in secondary will rise. It thus follows that governments will need to implement a cluster of policies which create an enabling environment for the expansion of secondary and tertiary education. The financing of universal secondary education for low-income countries would not be possible without an immediate steep-change in the volume and quality of donor support. Whatever is done to mobilize internal resources at the country level, better quality, as well as more aid is urgently needed to achieve free secondary education.

According to Manda, Mwabu and Kimanyi (2002), the government should always be the principal investor in education. Such a role cannot be left entirely to the private sectors because human resources development involves long-term planning and substantial financial resources mobilization. On the other hand, education, particularly post-primary education, can be treated as a profitable investment for individual graduates, who earn more than they would otherwise, and for the society, which is enriched not only by the knowledge of the educated people but also by the higher taxes paid by educated individuals. This benefit extends from the students present household, future household and to the economy.

Despite the relatively high expenditure on education in Kenya, the GER in secondary education was 31 percent in 2006 (UNESCO, 2008). Lewin (2007b) suggest that to achieve GERs 100 percent in primary, 100 percent in lower secondary and 50 percent in upper secondary, approximately 8.6 percent of GNP would be required for spending on education without any cost saving reforms; or 6.3 percent of GNP with cost savings reforms. With cost saving reforms, cost per pupils as a percentage of GNP per capita are calculated as 12 percent in primary, 20 percent in lower secondary education and 40 percent in upper secondary education, as compared with without cost saving reforms of 12 percent in primary, 30 percent in lower secondary and 60 percent in upper secondary education.

The study seeks to determine

a) What is the magnitude of investment in secondary education

b) Are schools in siaya District viable in respect to debt accrued by individual student 
c) What strategies can be put in place to enhance investment options

\section{METHODOLOGY}

This study adopted descriptive (survey) and causal-comparative (ex-post facto) designs. The study was carried out in Siaya district. Study population comprised 85 head teachers', 749 teachers', 3,210 form 4 students, and one DEO. Stratified, systematic and purposive sampling methods were used. Stratified sampling is a variation of simple random sampling and stratified sampling helps to reduce the sampling error that may otherwise be there as a results of simple random sampling. Systematic sampling was used in the selected schools to determine the teachers and students who would be given questionnaires and who would participate in the interview. The researcher developed questionnaires and semi-structured interview schedules for the purpose of collecting data.

\section{RESULTS AND DISCUSSION}

\section{Government Expenditure in Secondary Schools, Siaya district}

The government expenditure in the period 1997-2007 was mostly in training and remuneration of teachers, provision of bursaries, administration and management of schools.

\section{Remuneration of Teachers}

Teachers are an important human resource in the learning process. Teachers' remuneration constitutes one of the main inputs of the cost of secondary education costs. Secondary schools teachers are on average attract higher salaries. Table 1 shows teacher salary for various grades for the period 1997 to 2007.

Table 1: Salary of Teachers Per Annum (in Ksh.)

\begin{tabular}{lrrrr}
\hline Year & Graduate 11 & \multicolumn{1}{l}{ Graduate1 } & \multicolumn{1}{l}{ Senior Lecturer } & Principal Lecturer \\
\hline 1997 & 98,364 & 109,680 & 122,040 & 136,680 \\
1998 & 109,680 & 122,040 & 136,680 & 154,440 \\
1999 & 122,040 & 136,680 & 154,440 & 179,880 \\
2000 & 136,680 & 154,440 & 179,880 & 204,480 \\
2001 & 154,440 & 179,880 & 204,480 & 247,200 \\
2002 & 179,880 & 204,480 & 247,200 & 269,700 \\
2003 & 212,040 & 243,240 & 290,760 & 316,920 \\
2004 & 228,384 & 260,580 & 313,260 & 338,136 \\
2005 & 244,728 & 277,920 & 335,760 & 359,352 \\
2006 & 261,072 & 295,260 & 358,260 & 380,568 \\
2007 & 277,416 & 312,600 & 380,760 & 401,784 \\
2008 & 293,760 & 329,940 & 403,260 & 403,940 \\
\hline
\end{tabular}

Source: Kenya Gazette Supplement No.68 (Republic of Kenya, 2003a).

From the Table 1, teachers of all grades, had their salary doubled by 2003 and tripled by 2008. In 1997, the salary grade II was Ksh.109, 680. It doubled in 2003 at 204,480 tripled to Ksh.329, 940 by 2008 . Other grades reflected the same trend. The high salary level was supposed to motivate and encourage teachers to work hard. It was hoped that high salary will translate into good grades for students. Teachers' expressed a concern about the amount of work they do. 
With many feeling that they are overloaded with long teaching hours. Table 2 shows periods per week for sampled teachers in secondary schools

Table 2: Teaching Periods Per Week

\begin{tabular}{lrr}
\hline No. of Teaching Periods & Frequency & \multicolumn{1}{c}{ Percent } \\
\hline $1-10$ & 4 & 2.6 \\
$11-20$ & 50 & 32.5 \\
$21-30$ & 81 & 52.5 \\
$31-40$ & 20 & 12.9 \\
Total & 155 & 100 \\
\hline
\end{tabular}

Source: Authors' calculation

From Table 2, 52.5 percent of sampled teachers teach between 31-40 periods per week especially those who are alone in one subject. About 33 percent of sampled teachers teach between 11-20 periods per week and most principals, deputies and heads of department teach between 1-10 periods per week. There may be several reasons why teachers' are underutilized: (a) a proportion of these teachers' are teaching in the schools that do not have large student enrollment; (b) these teachers are only teaching one subject, rather than two or three; or (c) only one subject is offered in the area. About 12.9 percent of sampled teachers' teach between 31-40 periods per week. Such teachers' are often overburdened.

\section{LABORATORY AND EQUIPMENT GRANT}

Following the government resolve to strengthen mathematics and sciences in secondary schools, there was need to supply secondary schools with grants for laboratory and equipment so that schools without laboratory can construct and repair the existing ones while those that have no equipment were supplied with those equipment that were missing. Table 3 shows laboratory and equipment grants allocated to secondary schools between 2003/4 to 2007/08 in Siaya district.

Table 3: Laboratory and Equipment Grant

\begin{tabular}{lr}
\hline Year & Grant (in Ksh. Millions) \\
\hline $2003-2004$ & $1,859,757$ \\
$2004-2005$ & $1,286,148$ \\
$2005-2006$ & $2,274,560$ \\
$2006-2007$ & $2,021,830$ \\
$2007-2008$ & $1,114,860$
\end{tabular}

Source: Authors' calculation

Table 3 shows that in 2003/04 the government grants towards laboratory and equipment was Ksh. 1, 859, 757.The amount dropped to Ksh. 1, 286, 148 in 2004/05 before rising to Ksh. $2,274,560$ in 2005/06. From table 3 the government contribution has been fluctuating. However, in order to realize the vision 2030, the government should increase allocation for all district day secondary schools.

\section{Bursary to Secondary Schools in Siaya District}

Bursary and grants to needy students constitute one of the poverty mitigation measures for secondary education. Table 4 shows the amount of bursary allocated. 
Table 4: Bursary Allocation to Secondary Schools (in Ksh. millions)

\begin{tabular}{lrrrr}
\hline Year & ALEGO & GEM & UGENYA & TOTAL \\
\hline 2008 & $6,292,000$ & $2,952,300$ & $3,453,914$ & $9,325,214$ \\
2007 & $4,105,16$ & $3,796,748$ & $4,668,090$ & $12,570,107$ \\
2006 & $3,678,116$ & $3,770,172$ & $4,599,760$ & $12,047,048$ \\
2005 & $5,093,192$ & $3,381,043$ & $4,424,020$ & $12,898,256$ \\
2004 & $3,214,148$ & $1,200,000$ & $4,303,582$ & $8,717,730$ \\
2003 & $1,121,343$ & 986,543 & $1,165,699$ & $3,272,585$ \\
2002 & $1,108,677$ & 968,780 & $2,196,128$ & $3,272,585$ \\
2001 & $1,114,233$ & $1,002,500$ & $1,154,632$ & $3,270,365$ \\
2000 & $1,013,741$ & $1,102,343$ & $1,054,181$ & $3,170,265$ \\
1999 & $1,020,676$ & $1,010,200$ & $1,119,473$ & $3,150,343$ \\
1998 & $1,002,506$ & 976,356 & 922,105 & $3,010,967$ \\
1997 & $1,110,406$ & 763,540 & $1,083,730$ & $2,957,676$ \\
\hline
\end{tabular}

Source: District Education Office (2007).

Alego constituency received Ksh.1,110,406 in 1997 and it remained fairly constant between 1998 and 2003 averaging at Ksh.1,100,000. In 2004, the constituency received Ksh. 3,214,148 and Ksh.5,093,192 in 2005, this increased to Ksh.6,292,000 in 2008. Gem constituency did not receive much in terms of bursary allocation. In 1997, it received Ksh. 763,540. This increased to Ksh.1,002,500 in 2001 before reducing in 2002 and 2003. In 2004, the constituency received Ksh.1,200,000 which increased to Ksh.3,796,748 in 2007 before dropping to Ksh.2,952,300 in 2008. Ugenya constituency received Ksh.1,083,730 in 1997. Though fluctuating, it has remained fairly constant from 1999 to 2004. In 2005, it increased to Ksh. 3,381,043 and remained constant and in 2008, it dropped to Ksh.3,453,914. The total bursary allocation for the district increased in average from Ksh.2,957,676 in 1997 to Ksh. 3,272,585 in 2003 before increasing to Ksh.8,717,730 and steadied at an average of Ksh.12,100,000 between 2005 and 2007. Therefore one can argue that the government through bursary awards schemes and grants has been in the forefront in ensuring that the needy and most vulnerable children get secondary education.

Figure1 shows the total bursary allocation for the district. It indicates an upward trend from Ksh. 2,957,676 to Ksh. 12,570,102 for the period 1997 to 2007. The period 2004 to 2007 indicate a rise of the government funding for the district to the tune of Ksh. 12,570,102 from a Ksh.8, 717,730. 


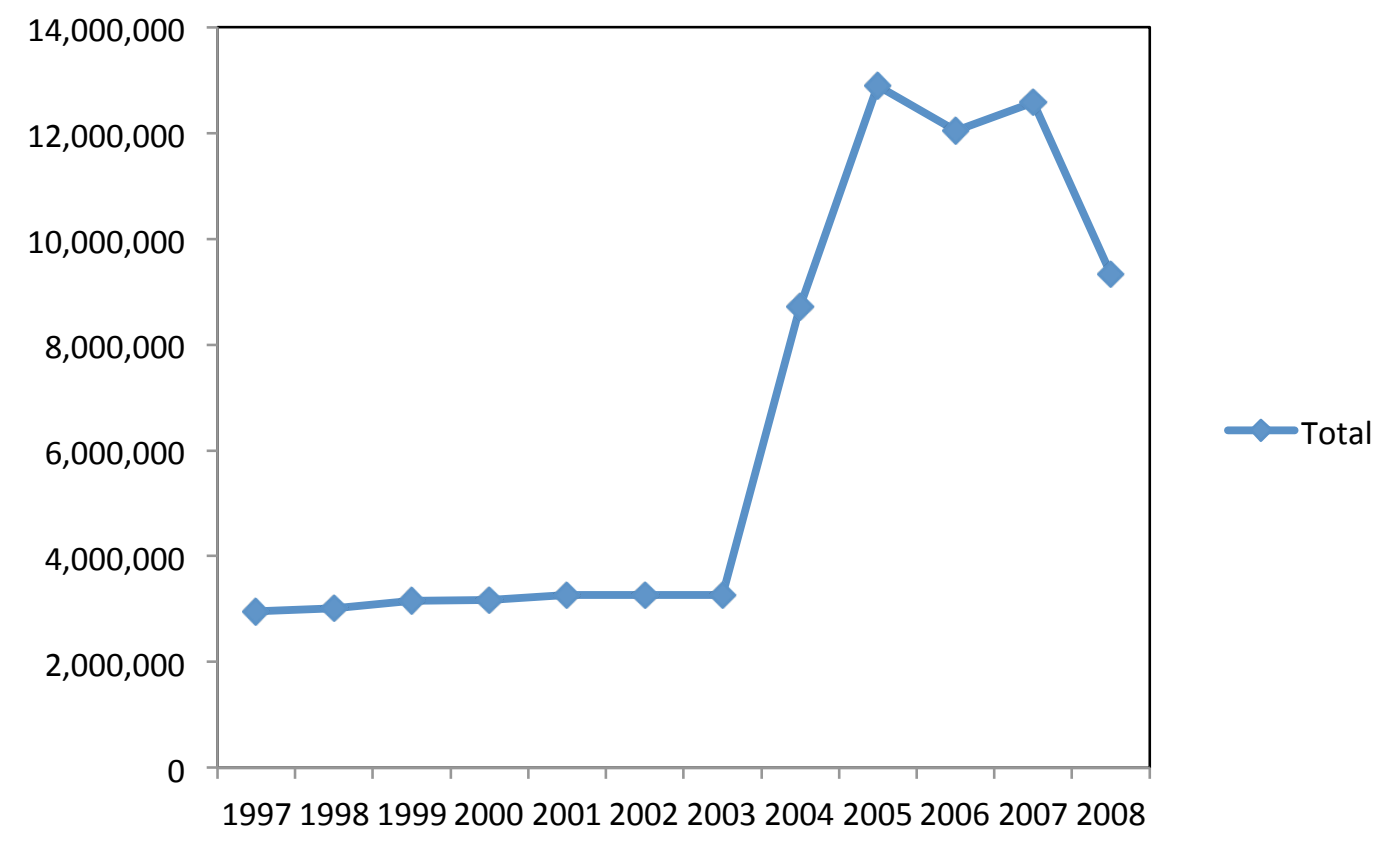

Figure 1: Bursary for secondary schools, Siaya district

\section{Household Expenditure in Secondary Education}

Households have to pay fees for their children to gain secondary education. Household income level increases the odds of a household decision to enroll a child in secondary school. This implies that the higher the level of household income, the higher the probability of enrolling children in secondary schools. Low income implies that a household can only squeeze its budget to cater for most basic needs. However, the overall effect of these inadequacies is limiting the capacity of household to take their children to school.

\section{Parental Income}

Parental income indicates ability to pay fees and consequently, ability of students to stay and learn in school without being sent home for fees. Table 5 indicates levels of parental income.

Table 5: Level of Parental Income

\begin{tabular}{lrc}
\hline Income level & Frequency & percent \\
\hline High income & 3 & 12 \\
Average income & 13 & 52 \\
Low income & 16 & 64 \\
Orphaned children & 2 & 8 \\
Total & 25 & 100 \\
\hline
\end{tabular}

Source: Source: Authors' Calculation

It is evident from Table 5 that 64 percent of parents are from low income regions of Siaya district. 8 percent constitute orphans while 52 percent are average income households. High income family consists of about 12 percent. Low income families are not able to complete the payment of fees. A large percent of student's population comes from such poor households. Average income families who comprise 52 percent of the household. Orphaned children comprise 8 percent of students' population. They rely on grants from the government, churches and CDF. Such students pose challenges to the school heads as they have to learn but 
at the same time they have not paid fees. In some cases their certificates are detained pending full payment.

\section{Issues of Fee Payment}

Households in Siaya were expected to pay fees according to ministerial guidelines. Table 6 shows the levels of completion of fee payments.

Table 6: Levels of Completion of Fee Payment

\begin{tabular}{lrr}
\hline Fee payment & Frequency & Percent \\
\hline Completion of fee in time & 3 & 12 \\
None completion of fee in time & 19 & 76 \\
Do not complete at all & 13 & 52 \\
Total & 25 & 100 \\
\hline
\end{tabular}

Source: Authors' Calculation

From Table 6, it is evident that 76 percent of students do not complete the payment of fee in time. Those who complete the payment comprise only 12 percent of sampled schools and 52 percent of students from sampled schools do not complete at all and have their certificate detained. The following measures have been adopted by Headteachers to recover fees: (a) sending students home; (b) holding certificates pending completion of fee payment; (c) adopting monthly fee payment; (d) seeking bursary from CDF; (e) holding regular discussion with parents; (f) introducing meal cards; (g) retention of term certificates.

\section{Fee Defaulters/Fee Arrears Per Annum}

Fee defaulting is phenomenon that affects performance of students and the school. Students who default in payment are frequently sent home to collect fees. Lack of fee payment has had a negative influence on access to secondary schools. Table 7 shows the annual fee arrears in secondary schools in a year.

Table 4.2.7: Fee Defaulters

\begin{tabular}{lrr}
\hline Fee (in Ksh.) & Frequency & Percent \\
\hline Arrears & 3 & 12 \\
$0-500,000$ & 14 & 56 \\
500,001-1million & 11 & 44 \\
1million-3millon & 6 & 24 \\
3million-10 million & 25 & 100 \\
Total & & \\
Defaulters & 12 & 48 \\
0-200 & 8 & 32 \\
201-300 & 4 & 16 \\
$301-400$ & 4 & 16 \\
Over 400 & 25 & 100 \\
Total & & \\
\hline
\end{tabular}

Source: Authors' Calculation 
From Table 7, 56 percent of sampled secondary schools are owed between Ksh. 500,001 to Ksh.1 million, 44 percent between Ksh.1million to Ksh.3 million and about 24 percent between Ksh.3million and Ksh.10million. Twelve (12) percent of sampled secondary schools have fee defaulters in the range of $0-500,000$. The table also show that fee defaulters in the range of 0 200 comprise 48 percent, 201 -300 comprise 32 percent. In the range of 301-400 comprise 16 percent and over 400 comprise 16 percent. The implication of this situation is that 80 percent of student populations are fee defaulters and therefore it is difficult to manage a one or two streamed secondary school.

\section{Actual Fees Paid by Households in Siaya District}

Table 8 shows various vote heads facing each student in secondary school. The vote heads are in fact unit cost facing individual students in secondary school which they must pay in order to gain secondary education.

Table 8: Fees Paid in Siaya District (in Ksh.)

\begin{tabular}{lrrrrrrrrrrr}
\hline Items & $\mathbf{1 9 9 7}$ & $\mathbf{1 9 9 8}$ & $\mathbf{1 9 9 9}$ & $\mathbf{2 0 0 0}$ & $\mathbf{2 0 0 1}$ & $\mathbf{2 0 0 2}$ & $\mathbf{2 0 0 3}$ & $\mathbf{2 0 0 4}$ & $\mathbf{2 0 0 5}$ & $\mathbf{2 0 0 6}$ & $\mathbf{2 0 0 7}$ \\
\hline Board & 8200 & 8500 & 8900 & 9000 & 9200 & 9500 & 10500 & 11600 & 12500 & 13400 & 14500 \\
Tuition & 2700 & 2700 & 2700 & 2700 & 3000 & 3000 & 3600 & 3600 & 3600 & 3650 & 3650 \\
P.E & 2400 & 2400 & 2700 & 2700 & 3000 & 3200 & 3300 & 3500 & 3600 & 4000 & 4565 \\
R.M.I & 500 & 500 & 500 & 500 & 500 & 500 & 500 & 500 & 500 & 800 & 800 \\
Activity & 500 & 500 & 500 & 500 & 800 & 800 & 800 & 800 & 800 & 900 & 900 \\
Medical & 200 & 200 & 200 & 200 & 200 & 200 & 200 & 200 & 400 & 400 & 400 \\
L.T\&T & 600 & 600 & 600 & 675 & 675 & 675 & 800 & 800 & 1000 & 1000 & 1000 \\
E.W.C & 600 & 600 & 600 & 600 & 600 & 600 & 600 & 800 & 800 & 800 & 800 \\
Conti. & 400 & 450 & 450 & 450 & 450 & 500 & 600 & 600 & 600 & 900 & 900 \\
PTA & 2000 & 2000 & 2000 & 2000 & 2000 & 2000 & 2000 & 2000 & 2000 & 2000 & 2000 \\
Dev. & 3000 & 3000 & 3000 & 3000 & 3000 & 3000 & 3000 & 3000 & 3000 & 3000 & 3000 \\
Lunch & 1500 & 1500 & 1500 & 1500 & 1500 & 1500 & 1500 & 1500 & 1500 & 1500 & 1500 \\
Caution* & 500 & 500 & 500 & 500 & 500 & 500 & 500 & 500 & 500 & 500 & 500 \\
Mock* & 1000 & 1000 & 1000 & 1000 & 1000 & 1000 & 1000 & 1000 & 1000 & 1000 & 1000 \\
Smasse & - & - & - & - & - & - & 200 & 200 & 200 & 200 & 200 \\
KNEC* & 3700 & 3700 & 3700 & 3700 & 3700 & 3700 & 3700 & 3700 & 3700 & 3700 & 3700 \\
\hline & & & & 50000 &
\end{tabular}

\section{Source: Authors' Derivation}

*caution money - only form one and new students

*mock - only form 4 students

*KNEC - only form 4 students

From Table 8, the boarding cost has been increasing from Ksh.6,000 in 1997 to Ksh.13,100 in 2007.The tuition fee was Ksh. 2,700 in 1997 and by 2007 it increased to Ksh.3,650. Personal emolument (PE) increased from Ksh.2,400 in 1997 toKsh.4,565 in 2007. In between it increased with changes being noted in various years. Repair, Maintenance and Improvement was Ksh.500 in 1997 and it remained constant in the period between 1997 to 2005. Between 2006 and 2007 it rose Ksh. 800 . Activity fee rose from Ksh. 500 in 1997 to Ksh. Ksh.800 from 2001 to 2005. It remained Ksh. 800 between 2006 and 2007. Medical fee remained fairly constant at Ksh.200 from 1997 to 2004. It rose to Ksh.400 between 2005 and 2007. Local 
transport and traveling experienced increases from Ksh.600 in 1997 to Ksh.800 in 2003 before increasing to Ksh.1000 between 2005 and 2007. Electricity, Water and conservancy also remained fairly constant at Ksh.600 between 1997 to 2003 before rising to Ksh.800 between 2004 to 2007. Contingency experienced an upward trend from Ksh.400 in 1997 to various increases reaching Ksh.900 in 2007. PTA fees remained constant at Ksh.2,000 from 1997 to 2007. Mock exam fees remained constant most of the year at Ksh.1000. Most day schools charged lunch program at Ksh. 1,500 per year, development fee at Ksh. 3,000 per student per year. New student were charged caution money amounting to Ksh. 500 per year while form fours were charged examination fees to the tune of Ksh. 3,700 per candidates.

\section{Extra Levy Paid by Students}

Secondary schools in the district often organize mandatory holiday tuition in which students are supposed to pay cash money directly to teachers. The amount paid is not factored as part of the school fees but regarded as extra charges to students. Table 9 shows the levels of extra charges.

Table 9: Extra Levy on Students

\begin{tabular}{lrr}
\hline Charges & Frequency & Percentage \\
\hline Less than Ksh. 500 & 59 & 38 \\
Ksh.501-100 & 67 & 43 \\
Over Ksh. 1000 & 28 & 18 \\
Total & 155 & 100 \\
\hline
\end{tabular}

Source: Authors' Calculation

Those charging less than Ksh.500 of sampled teachers were 38 percent and 43 percent charge between Ksh.501-1000 and 18 percent of sampled teachers charge over Ksh.1000 and are mostly provincial schools. The main argument advanced for extra levies is that they enable teachers to cover syllabus.

\section{Cost Incurred by Students in the Process of Learning}

The process of learning has various associated costs which parents must incur directly. Table 10 shows these associated cost categories.

Table 10: Costs Incurred by Students

\begin{tabular}{lrr}
\hline Cost (in Ksh.) & Frequency & Percent \\
\hline Travelling: & & \\
Less than Ksh.50 & 179 & 28.79 \\
Ksh.51-100 & 199 & 31.99 \\
$\quad$ Total & 625 & 100 \\
Pocket Money: & & \\
Ksh.1-500 & 318 & 50.88 \\
Ksh.501-1000 & 134 & 21.44 \\
Over Ksh.1000 & 62 & 9.92 \\
Total & 625 & 100 \\
Private tuition: & & \\
Ksh.1-100 & 67 & 10.72 \\
Ksh.200-499 & 65 & 10.4 \\
Ksh.500-1000 & 325 & 52 \\
Total & 625 & 100 \\
\hline \multicolumn{2}{c}{ Source: Authors' Calculation }
\end{tabular}


Transport cost incurred by sampled students varies from Ksh.50 to Ksh.100 depending on the distance covered to school. Pocket money for daily use for purchase of pens, books and stationeries cost students between Ksh.500 and Ksh.1000. About 51 percent of sampled students receive up to Ksh.500 as pocket money. It was observed that students having pocket money from Ksh.500 and above are in boarding schools while those having below Ksh.500 are in day schools. Private tuition costs students about Ksh.100 to Ksh.1000. Day schools charge between Ksh.500 and Ksh. 1000 for tuition per term. Boarding schools charge between Ksh.1000 to Ksh.2000 per term.

\section{Retraining of Teachers}

One of the most enduring puzzles for educationist in Kenya is the continued under achievement in Mathematics and sciences by students. In Siaya district every year all science and mathematics teachers have to attend a two weeks residential workshop dabbed SMASSE workshops for skill upgrading and to change teaching methodology. The cost implication of the program is normally borne by students who pay Ksh. 200 per year. This cost has to be factored into the school fees.

\section{Reducing costs of secondary Education to Households}

The findings indicate that 86 percent of parents are either low income earners or average income earners. The study shows that 93 percent have difficulties in completion of fee payment. Further to this, secondary schools are owed millions of shillings by fee defaulters. The implication is that secondary schools in Siaya district were inefficient in the provision of quality education.

One of the strategies of reducing cost related to secondary school education was to build day schools in Siaya district. Currently 85 percent of secondary schools in Siaya district are mixed day or single day secondary schools. The construction of new day schools is on the rise and it's expected that this will go a long way in reducing distance travelled by students to gain secondary education. It was also expected that this would eliminate the boarding aspect of secondary education fee. The current positioning of the schools creates a serious disadvantage to day scholars although this is subject policy and ministerial approval. For instance, many students avoid afternoon lessons due to distance between their areas of residence and the schools.

However according to Ohba (2009), although school fees facing household was reduced after the FDSE, there was no change in non-discretionary items that parents in secondary schooling in Kenya are paying. For instance, school uniforms are compulsory and the average cost would be a approximately Ksh.1,920 (US\$39) if purchased at a local market. Books and stationary are other expensive items parents have to purchase. Bibles, dictionaries, games skits and other items are a compulsory for all students. Although the cost of items vary, it can be estimated that direct costs for non-discretionary items for a day scholar could be Ksh.6,743 (US\$108) and Ksh.8443(US\$135) for a boarding scholar.

It's important to mention that bursary scheme and grants existed prior to the introduction of FDSE. According to Njeru and Orodho (2003) bursaries acts as safety- net in cushioning the poor and the vulnerable against poor access to secondary education. However, the bursary scheme has not been effective and efficient in meeting its objective as expected. According to Oyugi (2009) schools should develop their own initiatives to support needy students. In her study 87 percent of schools had come up with self initiative to help poor students. The main 
problem with bursaries is that 92 percent of recipients are not guaranteed continuous funding and hence those seeking funding are required to reapply.

Retraining of teachers need to be enhanced in the district, to sharpen teaching skills. A KESSP strategy for raising quality in secondary education is the pre-service and in-service training. Specifically cited is the enhancement of quality teaching, learning and performance, especially in KCSE science and mathematics with the teaching and learning being monitored and emerging issues addressed to ascertain cost-effectiveness and to produce desired results.

Students are subjected to unethical practices by the teachers' in contradiction with a Ministerial Circular No. INS/CON/53/36, of 2005 (MoE, 2005). The circular outlawed various unethical practices such as collecting tuition money, repetition and extra coaching. By forcing students to pay extra tuition fee between Ksh. 500 and Ksh. 2000, teachers' are subjecting student who are not able to pay the said amount to psychological torture. There is laxity in the DEO's office to ensure that such discriminating behavior is eradicated.

Secondary school education attracts government financing. The financing is mostly inform of teachers' remuneration, bursary and grants which is used for construction or buying of laboratory and equipment as well as catering for tuition fee for the needy students. The study findings show that the remuneration of teachers' salaries tripled from 1997 to 2007. The finding also shows that bursary and grants have been on upward trend. The government could reduce the cost of remuneration of teachers' by for example improving teacher utilization through increasing PTR in Siaya district. There was room to increase PTR in secondary school from the current 16:1 in 2007 to $45: 1$ without any requirement on extra teachers' and with the recommended class size of between 40 and 45 students (Republic of Kenya, 2005c).

The government could reduce the cost further by ensuring that underutilized teachers' are put to effective use. Currently in Siaya district 33 percent of teachers are underutilized. They teach between 1-20 lessons per week against the recommended range of between 25-27 lessons per week (Republic of Kenya, 2009). The findings are consistent with the findings of Ngware et al (2006a) who noted that teaching loads vary widely between schools, partly due to specialization and mastery in particular subjects. For instance, optional subjects are characterized by teacher under-utilization due to small class size. Under-utilization of teachers' can also be attributed due to under-enrolment in most district day schools with the existing gap averages at 75 percent and GER was averaging at 25 percent. It was expected that the introduction of FDSE would ensure that enrolment gap is reduced. However due to hidden cost of secondary education enrolment is likely to remain low.

The availability of bursary and grants could easily be enhanced through joint effort and partnership with donor support program. The bursary award scheme should specifically target students from poor families and those living under difficult conditions for example orphans, those living in arid and semi-arid lands parts of the district. Education partners in Siaya district include the Millennium Village Projects, World Vision, Africa Now, Academy for Educational development, Community Development Trust Fund, Simba Friends Foundation and Baje Community Projects. Ngware et al (2006a) emphasizes strong partnership between community and secondary schools to maximize on the benefit accrued from donors and stakeholders. According to Oyugi (2009), the government should provide clear guidelines on bursary allocation and determine who benefits from bursary fund as the children of the wealthy also benefit from the fund. 


\section{Reference}

Golding, C. \& Katz, L.F. (2007). The Race between Education and Technology: The evolution of U.S Education Wage Differentials, 1890 to 2005. NBER 1050 Massachusetts Avenue, Cambridge, MA 02138. March 2007. http://www.nber.org/paper/w12984.

Hertz, B. \& Sperling, G. (2004). What works in Girls Education?, Evidence and policies from the Developing World" Washington DC: IMF.

Lewin, K.M. (2006a). At the crossroads: Choices for Secondary Education in Sub-Saharan Africa. Washington D.C: World Bank.

Manda, D. K., Mwabu, G. \& Kimenyi, M. S. (2002). Human Capital Externalities and Returns to Education In Kenya. Nairobi: KIPPRA.

Ministry of Education (2009a).Guidelines on the implementation of Free Secondary Education: MOE/G1/9/09. Nairobi: Ministry of Education Publication

Ministry of Education (2005). Unethical Practices in Education. Ministry of Education Circular No. INS/CON/53/36, Nairobi: Ministry of Education publication.

Mugimu, B. C. (2004). Exploring the Relationships Between Critical Resource Variables and School Performance in Secondary Schools of Mukono Uganda. (Doctoral Thesis). Department of Educational Leadership and Foundations, Birgham Young University.

Ngware, M., Onsomu, E.N., Muthaka, D \& Kusimbei, G. (2007). Financing Secondary Education in Kenya; Cost Reduction and Financing Options. Education Policy Analysis Archives, 15(24). Retrieved from http://epaa.asu.edu/epaa/v15n24/.

Ngware, M., Onsomu, E.N., Muthaka, D \& Kusimbei, G. (2006a). Improving Access to Secondary Education In Kenya: What can Be Done? Nairobi, Kenya: KIPPRA \& Emerald Group Publishing Limited www.emeraldinsight.com/0261-0159.htm.

Ngware, M., Onsomu, E.N., Muthaka, D \& Kusimbei, G. (2006b). Financing of Secondary Education in Kenya: Costs and Options.DP/55/2006. Nairobi, Kenya: KIPPRA.

Njeru, E. H. N. \& Orodho, J.A. (2003). Access And Participation In Secondary School Education in Kenya: Emergency Issues And Policy Implication. Discussion paper No. 037/203. Nairobi, Kenya: IPAR.

OECD (2005). Education at a Glance: OECD Indicators. Paris: OECD.

Ohba, A. (2009). Does Free Secondary Education Enable the Poor to Gain Access? A Study from Rural Kenya. CREATE Pathway to Access Research Monograph No.21. Brighton, U.K: University of Sussex.

Oyugi, L.(2009). Expenditure Tracking of Secondary Education Bursary Scheme in Kenya. Nairobi, Kenya: IPAR.

Republic of Kenya (2009). Guidelines for the Implementation of Free Secondary Education. MOE/G1/9, Nairobi, Kenya: Government Printer.

UNESCO (2002). Managing Conflicts over Resources and Values: Continental Costs. Results of a Workshop on 'Wise Practices for Coastal Conflicts Prevention and Resolution'. Maputo, Mozambique, 19-23 November, 2001.Coastal Region and Small Islands Papers 12, Paris: UNESCO.

World Bank (2005). Education Sector Strategy Update: Achieving Education for All,Broadening our Perspective, Maximizing our Effectiveness. Washington DC: World Bank. 